\title{
ANALISIS WACANA PERCAKAPAN WARGA \\ DALAM GRUP FACEBOOK BUBUHAN SAMARINDA: IDENTIFIKASI POTENSI KONFLIK SOSIAL
}

\section{DISCOURSE ANAL YSIS OF CITIZENS CONVERSA TION IN FACEBOOK GROUP CALLED 'BUBUHAN SAMARINDA': IDENTIFICA TION OF POTENTIAL SOCIAL CONFLICT}

\author{
Ali Kusno \\ Kantor Bahasa Kalimantan Timur \\ ali.kusno@kemdikbud.go.id
}

\begin{abstract}
Abtsract
Samarinda, the capital city of East Kalimantan province are inhabited by various ethnic groups. Friction between residents and groups are frequent. Small conflict between residents involving different ethnic groups may widen into conflict of ethnic, religion, race, and inter group relationship called SARA. This study aims to identify potential conflicts with SARA nuances in Samarinda city through citizens' conversation discourse in Facebook group called 'Bubuhan Samarinda' (FBS). Identification of conversation was analyzed through FBS group. The FBS discourse represents the issue within Samarinda citizens. On the contrary, the opinion within FBS group influences citizens' life. This paper used critical discourse analysis from Fairclough. The data were gathered from the discourse conversation among FBS group members. The result shows that the conversations tend to use primordial statement dominated by ethnic factor. The primordialism sounds like propaganda of one ethnic group. There are the provocations of conflict between indigenous and the migrants, that shows social jealousy. There is also a stigma that immigrants only exploit the wealth of Borneo, which becomes a main problem in Samarinda. The potential violence arises from the existence of ethnic organization.
\end{abstract}

Keywords: conflict sara, Samarinda, critical discourse analysis, Bubuhan Samarinda.

\begin{abstract}
Abstrak
Samarinda adalah ibu kota Provinsi Kalimantan Timur yang dihuni oleh beragam suku. Gesekan-gesekan antarwarga dan kelompok sering terjadi. Konflik kecil antarwarga melibatkan kesukuan dapat melebar ke konflik SARA. Penelitian ini bertujuan untuk mengidentifikasi potensi konflik bernuansa SARA di Kota Samarinda melalui wacana percakapan warga dalam grup Facebook 'Bubuhan Samarinda' (FBS). Identifikasi percakapan warga melalui grup $F B S$.Wacana yang terbentuk dalam $F B S$ merepresentasikan isu yang berkembang dalam kehidupan warga Kota Samarinda. Begitu pula sebaliknya, opini yang terbentuk dalam grup FBS mempengaruhi kehidupan warga. Penelitian ini menggunakan analisis wacana kritis Model Fairclough.Data penelitian diambil dari wacana percakapan anggota grup FBS. Teknik analisis data menggunakan model interaktif. Hasil penelitian menunjukkan bahwa adanya potensi konflik bernuansa SARA yang didominasi faktor kesukuan. Hal itu didukung oleh tingginya primordialisme warga. Munculnya propaganda bahwa suku tertentu harus disegani. Adanya provokasi antara suku asli dengan pendatang yang lebih banyak dipicu kecemburuan sosial. Terbentuknya stigma bahwa pendatang menjadi biang masalah di Kota Samarinda karena hanya mengeksploitasi kekayaan Kalimantan. Potensi kekerasan menguat karena keberadaan organisasi massa yang mendasarkan pada kesukuan.
\end{abstract}

Kata kunci: konflik sara, Samarinda, analisis wacana kritis, Bubuhan Samarinda

\section{Pengantar}

Seperti provinsi lain di pulau Kalimantan, Provinsi Kalimantan Timur memiliki wilayah yang begitu luas. Khususnya Kota Samarinda memiliki luas wilayah 718 kilometer persegi dan berdasarkan sensus penduduk tahun 2013 berpenduduk 805. 688 jiwa (BPS, 2016). Kota Samarinda sebagai ibukota Provinsi Kalimantan Timur dihuni dari beragam suku. Sebagai ibukota provinsi sekaligus sebagai ibukota bagi suku-suku asli masing-masing kabupaten/kota di Kalimantan Timur.

Potensi sumber daya alam yang melimpah di Kalimantan Timur menjadi daya tarik bagi para pendatang. Perusahaan-perusahaan yang bergerak dalam komoditas batubara dan kelapa sawit tersebar di wilayah Kalimantan Timur. Geliat ekonomi dan pembangunan 
menarik banyak pendatang yang berasal dari beragam wilayah di Indonesia. Para pendatang itu bekerja di berbagai sektor usaha.

Bersamaan dengan masuknya pendatang tersebut, potensi gesekan antarkelompok warga yang berbeda suku pun meningkat. Tercatat beberapa kasus pertikaian antarsuku terjadi di wilayah Kalimantan Timur. Sebagai contoh pada tanggal 12 Juli 2007, pernah terjadi konflik di Nunukan, Kalimantan Timur. Konflik pribadi yang melebar menjadi konflik antara suku Dayak dan Bugis (Eka, 2007). Konflik berbau SARA juga pernah terjadi pada tanggal 26 September 2010 di Kota Tarakan. Bentrok antarkelompok warga terjadi di Kampung Juata Permai, Tarakan, Kalimantan Timur. Konflik pribadi yang kebetulan dari suku yang berbeda melebar menjadi konflik SARA antara warga suku Tidung dengan Suku Bugis Latta (Krisdiantoro, 2010).

Konflik bernuansa SARA pada November 2012, juga terjadi di wilayah Kabupaten Kutai Barat. Pasar Barong Tongkok di Kabupaten Kutai Barat menjadi sasaran amuk massa, menyusul konflik antara suku Dayak dan Bugis. Pasar dibakar oleh suku tertentu yang melakukan penyisiran terhadap toko, kios, dan rumah milik suku Bugis. Konflik tersebut terjadi berawal dari masalah pribadi antara warga Dayak yang tidak dilayani ketika membeli BBM di tempat pengisian milik warga Bugis (Vivaborneo.com, 2012).

Deretan konflik antarsuku di wilayah Kalimantan Timur membuktikan adanya potensi bencana sosial. Hal itu didukung hasil penelitian pada tahun 2013 oleh Dinas Sosial Provinsi Kalimantan Timur yang berhasil melakukan Pemetaan Daerah Rawan Bencana Sosial di lima kabupaten/kota Kalimantan Timur. Lima daerah tersebut yaitu Samarinda, Balikpapan, Penajam Paser Utara, Paser, dan Kutai Barat. Samarinda, sebagai ibukota Provinsi Kalimantan Timur, menduduki peringkat pertama sebagai kota yang memiliki kecenderungan konflik sosial tertinggi. Pemetaan tersebut bekerjasama dengan tim peneliti dan akademisi yang memberikan ringkasan singkat (executive summery) dan laporan hasil kerja dengan judul Kaltim Petakan Daerah Rawan Bencana. Selain pemetaan lima daerah yang rawan konflik itu, hasil penelitian juga mengungkapkan empat potensi konflik di Kalimantan Timur. Keempat potensi konflik itu adalah masalah SARA (suku,agama, ras, dan antargolongan), status kepemilikan lahan, perizinan, dan masalah sosial kemasyarakatan serta masalah pemerintahan(Timur, 2013: 124-125).

Konflik-konflik kecil yang terjadi di beberapa daerah kabupaten/kota di Kalimantan Timur dapat terakumulasi sehingga mengganggu ketahanan nasional. Konflik sosial di masyarakat dapat berujung pada bencana sosial di masyarakat itu sendiri. Oleh karena itu, diperlukan langkah-langkah identifikasi potensi konflik sosial di daerah, khususnya Kota Samarinda yang dihuni beragam suku. Menurut Koentjoroningrat dalam Narwoko (2004: 177), konsep yang tercakup dalam istilah suku bangsa adalah suatu golongan manusia yang terikat oleh kesadaran dan identitas akan kesatuan kebudayaan, kesadaran, dan identitas yang dikuatkan oleh kesatuan atau persamaan bahasa.

Gesekan-gesekan antarwarga dan kelompok warga sering terjadi di Kota Samarinda. Konflik kecil antarwarga dengan latar belakang kesukuan yang berbeda dapat melebar ke konflik SARA dalam skala besar. Isu konflik sosial dapat dalam bentuk konflik linguistik, misalnya perselisihan tentang kata siapa yang boleh digunakan, istilah-istilah apa yang digunakan kelompok satu untuk menyebut diri mereka sendiri dan menyebut lawan mereka (Thornborrow, 2006: 236). Konflik linguistik yang sering menimbulkan konflik sosial adalah penggunaan istilah-istilah untuuk menyebut lawan. Konflik liguistik ini khususnya pembentukan stereotip berupa pelabelan negatif suku tertentu sehingga lambat laun membentuk stigma di masyarakat.

Konflik linguistik yang bernuansa SARA banyak ditemukan dalam grup facebook 'Bubuhan Samarinda'. Grup tersebut merupakan kumpulan para pengguna facebook di Kota Samarinda yang per tanggal 29 September 2016 grup tersebut memiliki jumlah anggota sebanyak 154.227 anggota. Anggotanya pun beragam usia, pendidikan, suku, agama, maupun sosial. Isu yang dibahas terkait beragam permasalahan di Kota Samarinda. Wacana yang terbentuk dalam grup facebook 'Bubuhan Samarinda' merepresentasikan isu yang berkembang dalam kehidupan warga Kota Samarinda. Begitu pula sebaliknya, opini yang terbentuk dalam grup facebook 'Bubuhan Samarinda' mempengaruhi kehidupan warga. Konflik linguistik bernuansa SARA dikhawatirkan dapat menjadi konflik sosial (nyata) di Kota Samarinda. Oleh karena 
itu, tindakan preventif dengan mengidentifikasi potensi konflik penting dilakukan untuk mencegah bencana sosial di Kota Samarinda.

Tulisan ini meneliti wacana percakapan warga dalam grup facebook 'Bubuhan Samarinda' untuk menggambarkan faktor-faktor yang saling berkonflik. Dalam Pasal 1 Undangundang Nomor 7 Tahun 2012 tentang Penanganan Konflik Sosial (Undang-undang Nomor 7 Tahun 2012, 2012), konflik sosial dimaknai perseteruan dan/atau benturan fisik dengan kekerasan antara dua kelompok masyarakat atau lebih yang berlangsung dalam waktu tertentu dan berdampak luas yang mengakibatkan ketidakamanan dan disintegrasi sosial sehingga mengganggu stabilitas nasional dan menghambat pembangunan nasional. Dengan demikian, definisi ini menjadi patokan penulis untuk melakukan analisis identifikasi potensi konflik SARA dalam percakapan warga grup facebook 'Bubuhan Samarinda'.

Penelitian ini menggunakan metode kualitatif yang bersifat deskriptif. Metode penelitian kualitatif merupakan prosedur penelitian yang menghasilkan data deskriptif berupa katakata tertulis dan lisan tentang sifat individu, keadaan, gejala dari kelompok tertentu yang dapat diamati (Moleng, 1994: 6). Objek penelitian ini adalah penggunaan bahasa dalam percakapan warga dalam grup facebook 'Bubuhan Samarinda'. Data dan sumber data yang digunakan dalam penelitian ini berupa dokumen percakapan warga Kota Samarinda dalam grup facebook 'Bubuhan Samarinda' yang bernuansa SARA. Untuk menjaga kerahasiaan penutur dan keamanan penulis, penutur dan tuturan yang terkait SARA dalam percakapan tersebut penulis ganti dengan inisial. Sumber data dokumen percakapan dalam grup facebook 'Bubuhan Samarinda' periode bulan Juli s.d. September 2016.

Penelitian ini menggunakan analisis wacana. Menurut Djajasudarma (1993: 75) prinsip penafsiran dapat terjadi melalui penafsiran lokal (termasuk ruang dan waktu) dan prinsip analogi dalam menafsirkan pengertian (makna) yang terkandung dalam wacana. Dengan analisis wacana dapat dipahami bahwa "..discourse a word that constructs language as active: texts and talks in social practice" (Hepburn \& Potter, 2007). Untuk dapat mengidentifikan potensi konflik dalam grup facebook 'Bubuhan
Samarinda' analisis wacana yang digunakan analisis wacana kritis Model Fairclough.

Teks percakapan warga dalam grup facebook 'Bubuhan Samarinda' merupakan sebuah wacana. Menurut Purbani (2009: 1) istilah wacana memiliki pengertian yang beragam tergantung pada konteks apa yang tengah digunakan untuk memperbincangkannya. Secara umum wacana dimengerti sebagai pernyataan-pernyataan. Dalam ranah lingusitik, wacana dipahami sebagai unit kebahasaan yang lebih besar daripada kata atau kalimat, yang dapat melibatkan satu atau lebih orang. Jadi, sebuah pidato, dialog, polemik, perdebatan, percakapan atau perbincangan dapat dikategorisasikan sebagai sebuah wacana.

Crystal dan Cook dalam Nunan (Purbani, 2009: 2) mendefinisikan wacana sebagai unit bahasa lebih besar daripada kalimat, sering berupa satuan yang runtut/koheren dan memiliki tujuan dan konteks tertentu, seperti ceramah agama, argumen, lelucon atau cerita. Nunan melihat unsur-unsur keruntutan dan koherensi sebagai hal yang penting untuk menilai sebuah wacana. Lubis (Purbani, 2009: 2) mendefinisikan wacana sebagai 'kumpulan pernyataan-pernyataan yang ditulis atau diucapkan atau dikomunikasikan dengan menggunakan tandatanda.

Istilah wacana yang digunakan dalam Critical Discourse Analysis (CDA) salah satunya dikembangkan ahli linguistik sosial seperti Norman Fairclough. Analisis wacana kritis Model Fairclough menempatkan wacana atau penggunaan bahasa sebagai praktik sosial; wacana atau penggunaan bahasa dihasilkan dalam sebuah peristiwa diskursif tertentu; wacana yang dihasilkan berbentuk sebuah genre tertentu (Ahmadi F., 2014: 255). Apabila dikaitkan dengan penelitian ini, analisis wacana kritis Model Fairchlough menempatkan wacana atau penggunaan bahasa dalam grup facebook 'Bubuhan Samarinda' sebagai praktik sosial. Penafsiran wacana ini tidak bisa dilepaskan dari konteks sosial budaya warga Kota Samarinda. Wacana atau penggunaan bahasa grup facebook 'Bubuhan Samarinda' dihasilkan dalam sebuah peristiwa diskursif tertentu. Peristiwa diskursif itu dapat dipahami bahwa wacana yang dihasilkan merepresentasikan wacana yang berkembang dan tersebar dalam kehidupan warga Kota Samarinda. Penggunaan bahasa dalam wacana grup facebook 'Bubuhan 
Samarinda' juga dapat diidentifikasi genre atau jenis berdasarkan bentuknya.

Oleh karena itu, analisis wacana kritis model Fairclough dikenal dengan sebutan analisis tiga dimensi. Analisis tiga dimensi ini ialah analisis tekstual (level mikro) adalah,1) analisis deskriptif terhadap dimensi teks; 2) analisis praktik wacana (level meso) adalah analisis interpretatif terhadap pemproduksian, penyebaran, dan pengonsumsian wacana, termasuk intertekstualitas dan interdiskursivitas; 3) analisis sosiokultural (level makro) adalah analisis eksplanatif terhadap konteks sosiokultural yang melatarbelakangi kemunculan sebuah wacana (Fairclough dalam Ahmadi F., 2014: 255). Analisis dengan tiga dimensi tersebut akan dapat mengungkap pemaknaan sebuah wacana dalam grup facebook 'Bubuhan Samarinda' dengan lebih menyeluruh dan mendalam.

Teknik analisa data menggunakan model interaktif (Miles \& Huberman, 1992: 1920), yang terdiri atas tiga komponen analisis, yaitu reduksi data, sajian data, dan penarikan simpulan atau verifikasi. Aktivitas ketiga komponen itu dilakukan dalam bentuk interaktif dengan proses pengumpulan data. Hasil penelitian ini juga penulis verifikasi dengan melakukandiskusidengan berbagai ahli terkait, yakni ahli bahasa (Kepala Kantor Bahasa Kalimantan Timur dan Ketua Forum Bahasa Media Massa Kalimantan Timur), tokoh masyarakat (Ketua Pokja 30 Kalimantan Timur), dan pemerintah daerah (Dinas Sosial Provinsi Kalimantan Timur).

\section{Identifikasi Potensi Konflik Sosial di Kota Samarinda}

Dalam grup facebook 'Bubuhan Samarinda' terdapat percakapan-percakapan yang merepresentasikan kehidupan sosial warga di Kota Samarinda. Salah satu topik percakapan yang sering diangkat terkait kebijakan dan tindakan pemerintah Kota Samarinda yang dirasa belum memuaskan, seperti persoalan banjir, parkir liar, gelandangan dan pengemis, kebersihan kota dan persoalan lainnya. Selain itu topik percakapan lain juga diangkat, misalnya seputar premanisme, kriminal, dan keamanan lingkungan. Sering terjadi selisih pendapat yang berujung perdebatan saling menjatuhkan. Banyak ditemukan tuturan anggota grup facebook 'Bubuhan Samarinda' yang menyinggung SARA. Berikut ini analisis wacana kritis identifikasi potensi konflik sosial dalam percakapan wargadalam grup facebook 'Bubuhan Samarinda'.

\section{Analisis Tekstual (Analisis Mikro)}

\section{Struktur Teks}

Struktur teks biasa dibagi menjadi tiga bagian, yaitu bagian pembuka, bagian isi, dan bagian penutup. Teks-teks seperti pidato dan teks opini maupun pemberitaan di media merupakan contoh struktur teks yang memenuhi tiga bagian itu. Berbeda dengan struktur teks percakapan warga anggota grup facebook 'Bubuhan Samarinda' secara umum tanpa menggunakan pembuka dan penutup. Tuturan dalam grup ini relatif pendek-pendek dengan langsung menyampaikan isi tuturan. Selanjutnya secara substansi, isi teks tuturan itu mengungkapkan beberapa hal yang dapat diidentifikasi sebagai pemicu konflik bernuansa SARA di Kota Samarinda.

\section{a. Adanya Potensi Konflik Bernuansa SARA yang Didominasi Faktor Kesukuan}

Isu kesukuan sangat sensitif untuk menjadi bahan perdebatan publik termasuk dalam kehidupan warga Kota Samarinda. Oleh karena itu, ada sebagian oknum warga yang sengaja memanfaatkannya dengan mengunggah isu kesukuan untuk memancing/memprovokasi warga. Potensi konflik membesar apabila menyinggung suku asli Kalimantan Timur. Hal itu terbukti dalam salah satu tuturan warga berikut ini.

(1) ZB: Itu milik si J..... D...... Walikota Gila.

Konteks dari komentar ini adalah sebuah unggahan informasi yang menyebutkan bahwa salah satu SPBU di Samarinda mengoplos premium dengan air yang mengakibatkan banyak kendaraan yang mogok. Kasus tersebut berkembang menjadi isubahwa SPBU tersebut milik Walikota Samarinda, SJ. SJ merupakan keturunan dari suku Bakumpai asal Mangkahui, Kalimantan Tengah dan Suku Dayak Bahau Busang asal Datah Naha, Kabupaten Mahakam Ulu, Kalimantan Timur.

Pernyataan seperti dalam data (1) tersebut, "Itu milik si SJ D....... Walikota Gila" sangatlah provokatif. Oknum anggota grup facebook 'Bubuhan Samarinda' menjelekjelekkan Walikota Samarinda dengan mengatakan 'SJ D..... ' walikota gila. Tuturan tersebut telah 
memprovokasi warga Samarinda yang utamanya keturunan suku asli. Dalam tuturan tersebut kata 'D...' digunakan sebagai bentuk pelabelan negatif. Apabila bentuk pelabelan negatif terhadap suku tertentu terus dilakukan, dapat memperkuat stereotipe negatif yang telah ada. Stereotip negatif bernuansa kesukuan juga terlihat dalam penggalan percakapan warga dalam grup facebook Bubuhan 'Samarinda' berikut ini.

(2) VG, "Ngaku Dayak tapi namanya KAPS... situ D.... ato J...? Jangan bawa bawa Dayak, nanti km diincar baru tau rasa.

(3) MM, "Bah malah bahas suku bebungulan yg gini nih jd pemicu keributan....appun sukunya rasnya klo dia baik-baik..setiap suku ad baiknya ad jahatnya walai jd kda usah saling menthkan saling menjelek2kan... intinya samarinda milik bersama bangun bersama sapa yang merusak hancurkan..

Kedua tuturan ini disampaikan untuk menanggapi unggahan pemilik akun KAPS yang menyampaikan berbagai permasalahan yang ada di Kota Samarinda yang tidak mengindahkan lagi adat suku pedalaman Kalimantan. Seperti dalam data (2) dan (3) tersebut diungkapkan pernyataan VG yang menyerang salah satu anggota 'Bubuhan Samarinda' karena mengaku suku asli sedangkan bernama KAPS (nama yangmengarah ke salah satu suku pendatang). Penutur meminta yang bersangkutan agar tidak menambah isu stereotipe kesukuan yang ada. Penutur mengingatkan bisa saja yang bersangkutan (KAPS) justru yang diincarsuku asli tersebut.

Stereotip kesukuan yang dapat meningkatkan potensi konflik sosial juga diakui oleh penutur lain, seperti MM. Baginya pernyataanpernyataan yang menyinggung kesukuan dapat memicu timbulnya keributan. Penutur mengingatkan bahwa apapun suku dan ras pastilah ada yang baik dan ada juga yang jahat. Penutur mengingatkan tidak perlu saling menjelekkan suku satu dengan lain. Sebaiknya sesama warga Kota Samarinda memiliki kesamaan tekad untuk membangun Kota Samarinda dengan mengesampingkan kesukuan.

Konflik linguistik dalam data (1), (2), dan (3) tersebut secara keseluruhan menggambarkan potensi konflik sosial bernuansa kesukuan. Hal yang sama sering ditemukan dalam percakapanpercakapan lain dalam grup facebook 'Bubuhan Samarinda'. Konflik linguistik bernuansa SARA lain, seperti faktor agama, tidak sebanyak faktor kesukuan. Stereotip-stereotip negatif yang dilekatkan terhadap suku-suku tertentu dapat terakumulasi dan menjadi pemicu konflik sosial. Oleh karena itu, sebagai salah satu cara untuk memperkuat solidaritas kelompok adalah penggunaan bahasa, yakni memulihkan nada positif dari istilah-istilah yang selama ini digunakan dalam artian negatif (Singh, 2006:163).

\section{b. Tingginya Primordialisme Warga Kota Samarinda}

Primordialisme adalah sebuah pandangan atau paham yang memegang teguh hal-hal yang dibawa sejak kecil, baik mengenai tradisi, adatistiadat, kepercayaan, maupun segala sesuatu yang ada di dalam lingkungan pertamanya ("Primordialisme," 2016). Tingginya primordialisme warga tampak pada fakta bahwa warga suku asli berupaya mempertahankan adat-istiadat dan hukum adat agar juga dihargai para pendatang. Sebaliknya, warga pendatang juga memiliki primordialisme yang begitu tinggi dalam mempertahankan adat istiadatnya.

Berikut ini pernyataan-pernyataan warga dalam grup facebook 'Bubuhan Samarinda' yang mengungkapkan gambaran tingginya primordialisme warga Kota Samarinda.

(4) KAPS, "Pembunuh tidak manusiawi sepanjang Juli-Agustus, September 2016, Hasil Survei... Hukum adat rimba kalimantan udah gak berlaku, sehingga pelaku kejahatan semakin signifikan. kami suku asli D..... pedalaman kaltim turut, berduka,terluka atas kebiadaban ini.

Tuturan ini menggambarkanreaksi terhadap kasuskriminal yang terjadi di Kota Samarinda. Salah satunya yang memicu kemarahan warga Kota Samarinda adanya warga yang meninggal karena dijambret. Peristiwa tersebut menimbulkan banyak spekulasi salah satunya mengaitkannya dengan isu pendatang.

Pernyataan KAPS seperti dalam data (4) tersebut mengungkapkan berbagai kasus kriminal yang terjadi di Kota Samarinda. Kasus pembunuh tidak manusiawi sepanjang Juli, Agustus, dan September 2016. Bagi penutur, hal itu disebabkan hukum adat rimba Kalimantan (hukum adat suku asli) sudah tidak berlaku sehingga jumlah pelaku kejahatan semakin signifikan. Penutur yang mengaku sebagai bagian suku asli pedalaman Kalimantan Timur turut berduka dan terluka atas kebiadaban tersebut. 
Menurut penutur, berbagai kasus yang ada merupakan akibat diabaikannya hukum adat suku asli yang bermukim di pedalaman Kalimantan Timur.

Tuturan lain dalam grup facebook 'Bubuhan Samarinda' yang juga mengungkapkan tingginya primordialisme warga Kota Samarinda adalah sebagai berikut.

(5) SP, "Tu ingati bebaik jangan rusak adat kami oknum2 perusak, muyak2 ada jua kami turun sweaping para perusak sanggup kah kiranya bayar denda adat berupa kerbau gog atau bayar pakai kepala manusia ingati ini adat jangan disalahi belimbur tu sucikan diri lain merotaki.

Tuturan ini disampaikan sebagai tanggapan yang disertai tautan berita 'Warga dan Pengunjung Diharap Patuhi Adab Belimbur' sebagai salah satu prosesi dalam adat Eraudi Kota Tenggarong, Kutai Kartanegara. Erau (dalam bahasa Kutai berarti ramai, hilir mudik, bergembira, dan berpesta ria) merupakan pesta budaya tertua di Indonesia. Erau merupakan tradisi kerajaan Kutai Kartanegara yang diadakan sejak abad ke-13. Prosesi puncaknya berupa mengulur naga dan belimbur (siramsiraman di tempat acara dan di jalan-jalan). Pada saat prosesi Belimbur itulah ada oknum-oknum yang berbuat menyimpang dengan menggunakan air parit. Hal itulah yang memicu kekesalan warga.

Dalam data (5) tersebut, SP menyatakan bahwa keinginannya agar para pengunjung acara Erau, mengingat baik-baik jangan sampai merusak adat (salah satu suku asli). Penutur memberikan ultimatum apabila sampai membuat jengkel akan ada penyisiran yang mengharuskan orang-orang yang merusak adat untuk membayar denda. Denda adat biasanya berupa mandau (senjata tajam suku Dayak), gong, kerbau, dan piring bagi pelanggar hukum adat.Sedangkan bentuk denda seperti yang dituturkan oleh SP berupa potong kepala manusia dinamakan hukum adat Ngayau.

Tradisi Ngayau telah dihentikan sejak tahun 1874 berkat berlangsungnya Musyawarah Damai Perjanjian Tumbang Anoi yang juga dihadiri oleh Pemerintahan Kolonial Belanda. Masyarakat adat masih menerapkan denda adat berupa mandau, gong, kerbau, dan piring bagi pelanggar Hukum Adat. Penerapan hukum adat seperti ini pernah dilakukan terkait kasus yang menimpa sosiolog Universitas Indonesia (UI) Jakarta, Thamrin Amal Tomagola. Berdasarkan pemberitaan yang dimuat dalam laman Komisi Kepolisian Indonesia (BanjarmasinPost, 2011) Thamrin Amal Tomagola didakwa menghina, menista, dan melecehkan masyarakat adat Dayak terkait pernyataan sebagai saksi dalam sidang kasus video mesum dengan terdakwa Ariel Peterpan di Pengadilan Negeri Bandung, Jabar, 2 Desember 2010.

Saat itu Thamrin Amal Tomagola mengatakan, berdasar hasil penelitiannya, seks bebas bisa terjadi di kalangan masyarakat Dayak. Protes hingga aksi pun dilakukan masyarakat Dayak hingga berujung pada sidang adat. Thamrin Amal Tomagoladiputus bersalah. Usai sidang, Thamrin menjalani ritual adat Dayak berupa penyerahan lima pikul garantung (alat musik) gong yang menjadi denda. Selain itu, Thamrin juga menjalani prosesi tepung tawar sebagai tanda tidak adanya lagi perseteruan antara dirinya dengan masyarakat Dayak. Setelah itu, Thamrin menyerahkan biaya pelaksanaan sidang sebesar Rp77.777.700. Fakta itu meneguhkanbahwa hukum adat masih ada dan dijunjung tinggi oleh masyarakat Kalimantan. Atas dasar itulah penutur seperti dalam data (5) mengharapkan agar para pengunjung selalu mengingat bahwa itu adalah adat dan jangan sampai adat Belimbur disalahgunakan. Belimbur adalah acara untuk menyucikan diri bukan untuk merotaki (mengotori). Penutur mengaitkan pandangannya dengan tradisi, adat-istiadat, dan kepercayaan di lingkungan adat salah satu suku asli yang harus dihormati.

Perilaku primordialisme ditampakkan dengan upaya mempertahankan dan membela budaya masing-masing. Perilaku seperti itu lebih menguat apabila ada pihak yang menyinggung atau menghina adat dalam sukunya. Hal itu terlihat dalam tuturan berikut ini.

(6) AA, "Mohon kpd admin busam...postingan ini di hapus aja...takutx malah terjadi salah paham... karna sudah membawa nama suku..saya orang B...., cinta perdamaian...tp klo d jelek2in,,saya siap bela suku saya."

(7) RH, "Admin busam tolong!! Gunanya busam untuk hal seperti ini yah?? Untuk menjelek'an sesama budaya. Disin bisa kita hujat org yang bersalah tpi B.... (memakai huruf kapital) salah apa?? Hanya karna mengikut dgn budaya harus diolok' seperti ini." 
Kedua komentar ini muncul sebagai tanggapan atas sebuah unggahan salah satu warga, LA, yang menyampaikan, "Pulang $d r$ haji pa abiz carnaval yah...tp maaf aja hanya ingin bertanya nih.. kira kira, gimana mimik wajah, raut muka para begal jika seandainya berada di sekitaran situ.. apa seperti org yg lg kasmaran..???" dengan disertai foto prosesi adat B.....setelah pulang ibadah haji menggunakan pakaian adat dan perhiasan. Bagi warga yang bersuku lain dan tidak memahami adat tersebut dapat menimbulkan stereotip suku tersebut norak karena memamerkan perhiasan yang berlebihan. Stigma ini memang berkembang dalam kehidupan warga Kota Samarinda dan melekatkan stereotip tersebut dengan suku tertentu.

Dalam tuturan (6) dan (7) tersebut keduanya menyampaikan keberatan atas adanya unggahan yang terkesan merendahkan adat suku tertentu. AA dan RH, yang mengaku sebagai sebagai keturunan suku tersebut, meminta warga Kota Samarinda untuk tidak menghina adat mereka. Bahkan AA juga menyatakan kesiapan untuk membela suku tersebut karena dihina. Dalam data tuturan (4) s.d. (7) tersebut tampak menonjolkan pandangan etnisnya masingmasing. Dalam data (4) dan (5) merepresentasikan upaya warga menonjolkan kebanggaan terhadap suku asli. Sedangkan dalam data (6) dan (7) merepresentasikan upaya warga dalam mempertahankan adat dan tidak berkenan apabila ada pihak tertentu yang menghina sukunya. Potensi konflik mudah muncul apabila penghinaan dilakukan oleh oknum dengan latar belakang kesukuan yang berbeda.

\section{c. Adanya Upaya Propaganda Bahwa Suku Tertentu Harus Disegani}

Ada beragam pandangan yang berkembang dalam masyarakat Samarinda yang tergambar dalam percakapan warga dalam grup facebook 'Bubuhan Samarinda'. Salah satu yang menarik terkait perbedaan pandangan tentang suku asli di Kota Samarinda. Ada beragam pendapat terkait suku yang berhak mendapat predikat suku asli Kota Samarinda. Hanya saja, ada suku tertentu yang lebih menonjol. Bersamaan dengan perdebatan tersebut, muncul berbagai versi stereotip tentang suku asli Kalimantan, di antaranya terkait adanya 'ilmuilmu' tertentu. Atas dasar hal itulah terdapat stigma yang berkembang dalam masyarakat Kota Samarinda yakni agar jangan main-main dengan orang atau kelompok yang memiliki suku tersebut. Stigma seperti itulah yang berkembang dan seolah terus dipropagandakan. Propaganda perihal suku asli yang harus disegani utamanya para pendatang. Propaganda itu pun muncul dalam sela-sela percakapan warga dalam grup facebook 'Bubuhan Samarinda'.

Berikut ini beberapa percakapan dalam grup facebook 'Bubuhan Samarinda' tentang adanya propaganda suku asli yang terkesan pantas untuk ditakuti.

(8) MDI, "Suku apa yg jaga tuh, kurang ajar banaran, tunggu aja nanti saya bawakan org D.... mau turun dari pehuluan.... “

Tuturan ini konteksnya sama dengan data (1). Sesuai data (8) tersebut MDI mempertanyakan suku apa yang menjaga SPBU tersebut. Menurut MDI tindakan pengoplos tersebut sebagai bentuk kekurangajaran. Penutur melancarkan ancaman bahwa akan membawakan orang (suku asli)yang siap turun (datang) dari pehuluan (pedalaman). Pernyataan bernada ancaman tersebut pun mengundang beragam tanggapan dari angggota grup facebook 'Bubuhan Samarinda' yang lain, misalnya tanggapan salah satu warga yang mempertanyakan hubungan permasalahan tersebut dengan membawa-bawa suku. Jangan sampai pernyataan tersebut justru memperkeruh keadaan. Kalaupun ada masalah sebaiknya dibicarakan dengan baik-baik karena tidak ada hubungannya dengan suku. Berikut pernyataan lain yang juga bernada kesukuan sekaligus ancaman.

(9) CC, "jgn bawa2 nama bapakq... kena bisa aja mandau terbang ke leher.... pean"

Tuturan ini disampaikan CC, yang diduga warga Samarinda dengan latar belakang suku asli, terhadap anggota 'Bubuhan Samarinda' yang menghujat (bully) dirinya karena menanggapi tentang enaknya pada Zaman Soeharto. CC termasuk menentang pendapat tersebut. Tidak lama berselang banyak komentar pedas terhadap CC. Salah satu komentar menyinggung tentang Bapak (orangtua) CC. Hal itulah yang memicu kemarahan CC.

Pernyataan seperti dalam data (9) tersebut, CC mengancam anggota grup facebook 'Bubuhan Samarinda' agar tidak membawabawa nama orangtuanya (bapak) dalam perdebatan. Yang bersangkutan memberikan ancaman bisa saja mandau terbang ke leher pean (anda). Maksud ancaman tersebut terkait dengan 
adat tertentu. Penggunaan adat tersebut memungkinkan seseorang diserang dengan mandau terbang. Hal itu selaras dengan Laporan Akhir Pemetaan Daerah Rawan Bencana Sosial di Kalimantan Timur, bahwa di Kota Samarinda terdapat permasalahan adanya permasalahan ancaman mematikan pedang-pedang tradisional (Timur, 2013: 125). Masyarakat terutama sukusuku asli menyimpan pedang-pedang tradisional sebagai koleksi maupun sebagai senjata untuk berjaga-jaga. Kepemilikan benda-benda tersebut bagian dari adat suku tersebut. Sayangnya, ada oknum suku tertentu yang menggunakannya sebagai sarana membuat orang lain agar segan dan mendapatkan rasa hormat.

Ancaman memang menggoda seseorang untuk menggunakannya dan juga lebih efektif untuk mendatangkan kepatuhan (Pruitt \& Rubin, 2011: 122). Ancaman seperti dalam data (8) dan (9) tersebut merupakan bentuk aktualisasi identitas kesukuan. Dalam pandangan linguistik, memang kelompok-kelompok minoritas memiliki kebutuhan lebih besar untuk menekankan identitas karena seringkali diperlakukan sebagai orang luar oleh norma yang berlaku di kalangan mayoritas(Singh, 2006: 163). Suku-suku asli Kalimantan Timur, di Kota Samarinda, justru menjadi kelompok minoritas di antara masyoritas suku-suku pendatang. Oleh karena itu, berbagai upaya propaganda stereotipe-stereotip suku tertentu sebagai upaya menunjukkan eksistensi sebagai suku asli. Stereotipe-stereotip seperti itulah yang membentuk stigma di warga untuk tidak macam-macam dengan suku tersebut apalagi bagi seorang pendatang. Meskipun orang tersebut dalam posisi benar, lebih baik mengalah saja.

\section{d. Adanya Provokasi Konflik Antara Suku Asli dengan Pendatang}

Provokatif dalam KBBI Daring (Kemdikbud, 2016) dimaknai bersifat provokasi; merangsang untuk bertindak; bersifat menghasut. Berdasarkan definisi tersebut dapat dimaknai bahwa tindakan provokatif merupakan upaya merangsang atau menghasut khalayak untuk bertindak. Muatan provokasi terdapat dalam tuturan anggota grup facebook 'Bubuhan Samarinda' berikut ini.

(10) AAN," di sini benarai bubuhan ikam tu tenyaman jua hidup, mun dikampung sorang mencari sepiring nasi aja ngalih.
Tuturan ini disampaikan sebagai tanggapan adanya unggahan yang menyampaikan sebaiknya Gubernur Kalimantan Timur diganti Ahok karena dianggap kinerjanya buruk. Dalam kasus ini Ahok dianggap sebagai representasi pendatang, sedangkan AF sebagai representasi penduduk asli Kalimantan Timur.

Pernyataan dalam data (10) tersebut dapat dimaknai bahwa di Kalimantan benarai (benar saja) bubuhan ikam tu (para pendatang) tenyaman jua hidup (hidup nyaman), mun dikampung sorang mencari sepiring nasi aja ngalih (kalau di kampung sendiri mencari sepiring nasi saja susah). Penutur menyindir pengunggah yang menginginkan Ahok menggantikan AF. Penutur mengingatkan bahwa sebagai pendatang selayaknya bersyukur sudah mendapatkan nafkah di Kalimantan Timur dibandingkan di tanah kelahiran susah mendapatkannya. Pernyataan tersebut ditambah dengan dengan pernyataan lanjutan berikut ini.

(11) AAN, Kalau nda suka diam dikaltim minggat aja. Aku urang $K \ldots . . . \quad B . . .$. , penghinaan itu namanya....

Pernyataan seperti dalam data (11) tersebut dapat dimaknai bahwa apabila tidak suka tinggal di Kalimantan Timur khususnya di Samarinda sebaiknya pergi saja (meninggalkan Kalimantan Timur). AAN menyampaikan bahwa sebagai salah satu keturunan K..... B.... pernyataan bahwa Gubernur AF sebaiknya diganti dianggap sebagai sebuah penghinaan. Penghinaan tersebut tidak hanya dimaknai sebagai penghinaan terhadap diri Gubernur, tetapi juga penghinaan terhadap suku-suku asli Kalimantan Timur (AF keturunan suku asli).

Bentuk provokasi konflik antara suku asli dan pendatang juga terdapat dalam data berikut.

(12) ZB, "PEMILIKNYA SI J.....(huruf kapital) DAYAK BAKAR JAANG."

(13) FF, “Wewww hati2 mbak kalo ngomong"

$\mathrm{ZB}$, “ya”

MNM, "nanti dipenjara loh"

DA, "Jgn bawa2 suku"

ZB, "Dayak kamp... mna ada d..... kota”"

Tuturan ini konteksnya sama dengan data (1). Pernyataan dalam data (12) dan (13) tersebut seperti yang disampaikan ZB tersebut merupakan bagian dari pernyataan yang provokatif. ZB jelas-jelas mengeluarkan pernyataan yang menghina salah satu suku asli, dengan 
pernyataan, "D.... kamp... mna ada D.... kota". ZB menyampaikan pernyataan provokatif dengan membuat stereotip salah satu suku asli tersebut terbelakang, tinggal di kampung/ pedalaman, dan tidak ada yang tinggal di kota. Kata yang digunakan dengan memprovokasi seperti itu sering muncul dalam percakapan warga dalam grup facebook 'Bubuhan Samarinda' sebagai bentuk pelabelan negatif.

\section{e. Kecemburuan Sosial Antara Penduduk Asli dengan Pendatang}

Berbagai permasalahan Kota Samarinda, seperti banjir, kekumuhan, anak jalanan, pengemis, dan lainnya sering menimbulkan perdebatan dalam grup facebook 'Bubuhan Samarinda'. Perdebatan seperti itu sering muncul dan dihubung-hubungkan dengan keberadaan jumlah pendatang yang semakin bertambah. Hal itu ujung-ujungnya menimbulkan perdebatan antara penduduk asli dan pendatang. Salah satu contohnya ketika Gubernur Kaltim, $\mathrm{AF}$, ikut resah dan sempat curhat karena banjir yang terjadi di Samarinda. AF memberikan usulan agar Samarinda dijadikan kota tertutup, caranya dengan tidak lagi terima pendatang baru (Prokal.co, 2016). Pernyataan gubernur tersebut menimbulkan kesalahpahaman dan memicu perdebatan di masyarakat. Perdebatan pun melebar ke arah persoalan pendatang dan suku asli Kalimantan.

Sebenarnya pokok persoalan itu disebabkan adanya kecemburuan sosial. Perdebatan yang dipicu kecemburuan sosial dapat terlihat dalam tuturan salah satu warga dalam grup facebook ${ }^{`}$ Bubuhan Samarinda' berikut.

(14) RW,"Hebat pndatang memang hebat luar biasa. Penghasilan jukir liar sehari 150 ribu lebih... mkax bnyak org pndatang dri sulawesi jd jukir... parkir d psar pgi bwah jmbatan penyeberangan itu hbis di kuasai bubuhan S..... (salah satu pulau) mantab...uang 2 ribu jngn parkir dsitu."

Tuturan ini disampaikan sebagai tanggapan salah satu unggahan yang menyampaikan maraknya juru parkir dengan menarik uang parkir dengan tarif mahal. Sementara retribusi parkir tersebut tidak masuk ke dalam pendapatan daerah. Selain itu, banyak berkembang informasi bahwa banyak juru parkir tersebut adalah pendatang.

Pernyataan dalam data (14) tersebut RW mengeluhkan tentang keberuntungan juru parkir (jukir) liar yang dalam sehari berpenghasilan Rp150.000. RWberpandangan banyak pendatang dari pulau tersebut yang datang ke Samarinda untuk menjadi juru pakir. Pernyataan RW dengan menyinggung pendatang dari suatu pulau berarti juga menyinggung suku-suku yang terkait dengan pulau tersebut. Hal itu dapat membentuk stereotip bahwa suku-suku tersebut dianggap sebagai biang permasalahan di Kota Samarinda.

Sebaliknya RH seperti dalam data (15) mengingatkan agar (persoalan tersebut) jangan disangkutpautkan dengan suku tertentu.

(15) RH,"jgn di sangkut pautkan dgn suku suku...saya pun asli kalimantan ...ortu sya kalsel tp tidaklah kita untuk membawa suku kdlam hal ini tdk ada sngkut pautnya pelaku aja blm ktangkap jgn diponis msalah pendatang ...kalian yakin pelaku ialah pendatang?"

Tuturan ini disampaikan sebagai tanggapan adanya unggahan yang membicarakan tentang belum tertangkapnya pelaku jambret yang mengakibatkan meninggalnya salah satu warga. Ada yang mengaitkan hal itu dengan kemungkinan pelaku adalah pendatang. Penutur mengaku sebagai warga asli Kalimantan karena orangtuanya berasal dari Kalimantan Selatan. Meskipun demikian, penutur berpandangan bahwa tidaklah patut untuk membawa isu suku dalam persoalan jambret sebagaimana yang terjadi sebelumnya. Tidak ada sangkut pautnya masalah kriminal dengan kesukuan. Terlebih lagi pelaku saja belum tertangkap apalagi sudah diklaim pelakunya seorang pendatang. Kedua data tersebut menggambarkan adanya stereotip yang berkembang dimasyarakat bahwa para pendatang menimbulkan berbagai persoalan di Kota Samarinda.

\section{f. Persepsi Bahwa Pendatang Hanya Mengeksploitasi Kekayaan Kalimantan}

Kalimantan Timur sebagai daerah yang kaya dengan sumber daya alam merupakan sebuah kenyataan. Sayangnya,hal itu berbanding terbalik dengan kondisi warga atau masyarakatnya. Masyarakat Kalimantan Timur masih banyak yang hidup di bawah garis kemiskinan. Pembangunan infrastruktur masih terbelakang apabila dibandingkan dengan kondisi pembangunan di Pulau Jawa. Hal itu tentunya berimbas timbulnya stigma dalam masyarakat (asli) bahwa para pendatang hanya ingin mengeruk kekayaan Kalimantan Timur. Persepsi 
seperti itu juga berkembang dalam dialog warga dalam grup facebook 'Bubuhan Samarinda' berikut.

(16) CC, "liat papua... hasilnya dikeruk oleh para pejabat negeri ini dr jaman spa??? ... smpe mengakar...!!! Kasihan rakyat papua dan kalimantan yg ada dipelosok yg bnyak hasil kekayan alam gk menikmati hasilnya..."

Tuturan ini disampaikan CC terhadap anggota Bubuhan Samarinda yang ramai-ramai menghujat (bully) dirinya karena menanggapi salah satu postingan anggota grup facebook 'Bubuhan Samarinda' tentang enaknya pada Zaman Soeharto. CC termasuk menentang pendapat tentang kondisi masyarakat yang lebih sejahtera pada zaman Soeharto.Dalam tuturan (16) tersebut CC memaparkan fakta seperti di Papua yang kekayaan alamnya dikeruk seperti juga di Kalimantan Timur. Penduduk Kalimantan yang tinggal dipelosok yang memiliki banyak kekayaan alam, namun tidak menikmati hasilnya. Tuturan CC tersebut menguatkan adanya stigma bahwa pendatang hanya mengekploitasi kekayaan alam Kalimantan Timur.

Sebenarnya timbulnya berbagai stereotip seperti itu lebih disebabkan adanya kecemburuan sosial antara suku asli dengan pendatang. Hal itu selaras dengan Laporan Akhir Pemetaan Daerah Rawan Bencana Sosial di Kalimantan Timur, bahwa di Kota Samarinda terdapat permasalahan ketidakadilan masyarakat lokal dan pendatang (Timur, 2013: 125). Masyarakat lokal/penduduk asli justru terpinggir secara kesejahteraan. Keterpinggiran tidak hanya dalam hal berusaha, namun juga dalam pemerintahan. Kesenjangan dan ketidakadilan yang mengakibatkan kecemburuan sosial semakin menambah potensi konflik sosial di Kota Samarinda. Konflik sosial, terutama etnik, pada umumnya dapat terjadi kalau salah satu pihak merasakan sesuatu yang tidak adil baginya. Suku tetangga mungkin menduduki posisi yang dominan (unggul) terhadap suku lawannya. Hal ini dapat terjadi di bidang ekonomi, sosial, politik, pemerintahan, pendidikan, dan sebagainya (Soemardjan dalam (Ruslikan, 2001: 5).

\section{g. Potensi kekerasan yang menguat karena keberadaan ormas kesukuan}

Organisasi Kemasyarakatan (ormas) di Kota Samarinda cukup banyak dan beragam.
Diantara ribuan organisasi kemasyarakatan (ormas) di Kalimantan Timur tidak semuanya terdaftar. Berdasarkan data Badan Kesatuan Bangsa dan Politik (Kesbangpol) Kalimantan Timur, baru 358 sudah mengantongi Surat Keterangan Terdaftar (SKT). Ormas di Samarinda, Kalimantan Timur, diminta tidak menggunakan atau menonjolkan hal terkait agama atau kesukuan (Prokal.co, 2016). Faktanya, terdapat nama organisasi kemasyarakatan yang menggunakan nama yang cukup sangar dan ekstrem yang mengesankan konfrontatif. Ormas-ormas itu pun mengidentikkan diri dengan suku-suku tertentu dan cenderung ekstrem.

Menonjolnya ormas-ormas kesukuan menambahpotensi konflik sosial yang dapat terjadi di Kota Samarinda. Gesekan antarormas beberapa kali terjadi di Kota Samarinda. Terjadinya gesekan antarormas dapat merembet pada gesekan antarsuku. Berikut ini tuturan warga dalam grup facebook 'Bubuhan Samarinda' yang mengeluhkan keberadaan ormas kesukuan.

(17) BCM, "Kya bgini kah organisasi ormas yg beranggotakan peminum2, tngah $\mathrm{mlm}$ bgini memasuki rumah kami dng jumlah lbih 6 orng bersenjatakan parang badik,dgn asesoris kalung manik2 bersongkok songkok Dayak, memasuki rumah mencari org tnpa permisi tanpa bertanya dulu apa yg dicari dtng seenak bapak dan omq dihajar babak belur smpai patah tangan omku..Mereka mabuk2kan di gang kami tengah mlm tnpa salah org tua tersungkus hampri habis kehilangan napas sudah kami teriaki maling kami cewe $2 \mathrm{mw}$ melerai masak mreka buka parang panjang...sudah org kampung kami kluar smиa dgn sperti penjahat merwka lngsung lari2 bginikah cara ormas menyelesaikan masalah tnpa permisi dan tnpa ada kedamaian MANA SLOGAN DAN PRINSIP CINTA DAMAI ITU."

Tuturan ini disampaikan sebagai unggahan atas kejadian yang menimpa keluarga pengunggah. Pengunggah menceritakan tentang kejadian penganiayaan yang pelaku-pelakunya diduga oknumorganisasi massa tertentu.

Pernyataan BCM seperti dalam data (17) tersebut menyampaikan informasi dan kesaksian bahwa ada oknum ormas tertentu yang beranggotakan peminum (pemabuk). Pada waktu tengah malam memasuki rumah dengan bersenjatakan parang badik dengan aksesoris kalung manik-manik bersongkok-songkok salah 
satu suku asli. Anggota ormas tersebut memasuki rumah mencari orang tanpa permisi tanpa bertanya dahulu apa yang dicari dan langsung dihajar babak belur sampai patah tangan. Menurut BCM para anggota ormas tersebut memiliki kebiasaan mabuk-mabukkan di gang.

Pernyataan tersebut merupakan gambaran kecil stigma yang berkembang tentang keberadaaan ormas-ormas yang berkedok kesukuan yang menguatkan potensi kekerasan. Tindakan oknum ormas kesukuan meresahkan warga itulah yang membentuk stereotip bahwa ormas-ormas kesukuan sebagai pembuat onar dan berbagai aksi premanisme lainnya. Persoalan akan semakin rumit apabila terjadi gesekan antarwarga yang kebetulan anggota ormas kesukuan yang berbeda. Hal itu akan mudah melebar ke persoalan isu kesukuan.

\section{Penggunaan Gramatika Transitif}

Analisis tekstual pada bagian tata bahasa menurut Fairclough (Ahmadi F., 2014: 257), ada tiga aspek yang bisa dianalisis, yakni ketransitifan, tema, dan modalitas. Aspek ketransitifan berkenaan dengan fungsi ideasional bahasa, aspek tema berkenaan dengan fungsi tekstual bahasa, sedangkan aspek modalitas berkenaan dengan fungsi interpersonal bahasa (Eriyanto dalam (Ahmadi F., 2014: 257). Aspek ketransitifandalam percakapan grup facebook 'Bubuhan Samarinda' menunjukkan bahwa penutur menguatkan hal-hal negatif dan mengurangi hal positif terhadap suku yang berbeda. Terdapat penekanan terhadap stereotip negatif yang melekat pada suku tertentu. Tema kesukuan berkenaan dengan fungsi tekstual bahasa dalam grup facebook 'Bubuhan Samarinda' menggunakan tuturan yang memiliki dua motif, yakni sengaja mengangkat isu kesukuan dan yang tidak sengaja menyinggung kesukuan. Selanjutnya, fungsi modalitas dalam facebook 'Bubuhan Samarinda' berupa tuturantuturan-tuturan yang dapat memicu timbulkan konflik sosial.

\section{Penggunaan Kosakata}

Percakapan warga dalam grup facebook 'Bubuhan Samarinda'yang bernuansa SARA terdapat tuturan yang provokatif. Kesan provokatif tersebut terlihat melalui penggunaan kata. Selain itu, kesan provokatif juga tampak dalam penggunan kata yang menyinggung suku tertentu. Penutur memiliki kecenderungan menonjolkan kelebihan suku masing-masing. Kosakata para pengguna grup facebook 'Bubuhan Samarinda' yang bernuansa SARA menggunakan beragam gaya bahasa, seperti penggunaan bahasa secara langsung yang menyerang. Gaya seperti ini tampak dalam tuturan berikut, Kalau nda suka diam dikaltim minggat aja. Aku urang K.....B....., penghinaan itu namanya.... Selain itu, juga terdapat tuturan warga yang menggunakan bahasa kasar. Dorongan emosi dalam memberikan kritikan memunculkan kritikan dengan bahasa yang kasar (sarkasme). Sarkasme adalah suatu acuan yang mengandung kepahitan dan celaan yang getir (Keraf, 2006: 143). Tuturan dengan diwarnai emosional dari penutur terdapat pada percakapan warga grup facebook 'Bubuhan Samarinda'yang bernuansa SARA berikut, Itu milik si J..... D...... Walikota Gila.

Bahasa sindiran/ironi juga digunakan sebagian anggota grup facebook 'Bubuhan Samarinda'.Sebagian percakapan warga dalam grup facebook 'Bubuhan Samarinda' yang bernuansa SARA menggunakan sindiran/ironi. Ironi adalah suatu acuan yang ingin mengatakan sesuatu dengan kata atau maksud berlainan dari apa yang terkandung dalam rangkaian katakatanya. Ironi akan berhasil kalau pembaca juga sadar maksud yang disembunyikan di balik rangkaian kata-katanya (Keraf, 2006: 143). Gaya bahasa tersebut terdapat dalam tuturan warga dalam grup facebook Bubuhan Samarindayang bernuansa SARAberikut ini, Hebat pndatang memang hebat luar biasa. Penghasilan jukir liar sehari 150 ribu lebih..mkax bnyak org pndatang dri sulawesi jd jukir...parkir d psar pgi bwah jmbatan penyeberangan itu hbis di kuasai bubuhan sulawesi mantab...uang 2 ribu jngn parkir dsitu.

Selain itu, juga terdapat tuturan warga yang menggunakan bahasa menyerang/menuduh. Isi tuturan yang menyerang atau menuduh suku yang lain terdapat dalam percakapan warga anggota grup facebok 'Bubuhan Samarinda'. Berikut ini salah satu tuturan yang terlihat menggunakan serangan atau tuduhan. D.... kamp... mna ada d..... kota. Selanjutnya, juga terdapat tuturan warga yang mengunakan bahasa yang bernada ancaman. Salah satu tuturan yang bernada ancaman "jgn bawa2 nama bapakq.... kena bisa aja mandau terbang ke leher... pean. Penggunaan berbagai kosakata tersebut semakin 
menguatkan kesan kebencian dan permusuhan antarsuku yang ada di Kota Samarinda.

\section{Dimensi Praktik Wacana (Level Meso)}

Analisis teks dilanjutkan pada analisis praktik wacana. Menurut Failrlough (dalam Jorgensn dan Philips (Ahmadi F., 2014: 261). Analisis praktik kewacanaan ini dipusatkan pada bagaimana teks diproduksi dan dikonsumsi, termasuk di dalamnya menelisik proses apakah yang dilalui suatu teks sebelum dicetak dan perubahan apa yang dialami sebelum disebarluaskan. Dimensi ini sangat bermanfaat untuk menggali latar belakang sebuah tuturan dan akibat tuturan tersebut.

Teks percakapan yang bernuansa SARA diproduksi dalam percakapan warga dalam grup facebook 'Bubuhan Samarinda' terkait dengan berbagai persoalan di Kota Samarinda. Selain itu, percakapan sebagai tanggapan terkait dengan unggahan warga anggota grup facebook 'Bubuhan Samarinda'. Sering terjadi perdebatan antarwarga dalam percakapan tersebut. Perdebatanperdebatan dapat memunculkan berbagai tanggapan, diantaranya membawa hal-hal yang bernuansa kesukuan. Perdebatan yang membawa isu kesukuan sangat sensitif dibawa ke ranah media sosial seperti grup facebook 'Bubuhan Samarinda'. Percakapan tersebut menjadi konsumsi bagi masyarakat luas. Kondisi ini sangatlah rentan. Apabila konflik dalam dunia maya terjadi, bisa berdampak terjadinya konflik dalam kehidupan nyata di masyarakat. Terlebih lagi dengan adanya temuan Samarinda sebagai daerah paling rawan konflik sosial di Kalimantan Timur.

Contoh nyata konflik sosial bermula dari media sosial seperti dalam kerusuhan di Tanjung Balai, Sumatera Utara. Konflik tersebut dipicu pemberitaan di media sosial yang tidak valid. Seorang oknum mengunggah foto yang bernuansa provokatif saat proses mediasi berlangsung. Ada oknum yang menyebarkan berita provokatif dan negatif hingga membuat (oknum) warga bereaksi. Hal yang sama juga berpotensi terjadi di Kota Samarinda. Memang percakapan dalam grup facebook 'Bubuhan Samarinda' dilakukan oleh akun-akun asli ada juga akun fiktif. Penggunaan akun fiktif mengakibatkan kesulitan dalam melacak pemilik akun. Oleh karena itu, diduga terdapat akun-akun fiktif yang sengaja menyebar unggahan yang bernuansa SARA. Tujuannya tentu untuk memprovokasi antarsuku yang ada untuk saling bertikai. Tujuan akhirnya tentu menimbulkan rasa tidak aman dalam benak warga Kota Samarinda.

\section{Dimensi Praktik Sosial Budaya (Level Makro)}

Satu kenyataan yang harus dipahami bersama bahwa masyarakat adat (suku asli) di Kalimantan Timurmemang dikenal solid. Bila ada kelompok adat tertentu disakiti, hampir pasti seluruh suku yang sama akan ikut membantu. Solidaritas tersebut tidak sebatas individu dengan individu dari suku yang sama. Solidaritas tersebut juga sesama suku yang tidak sebatas pada wilayah provinsi, namun juga antarprovinsi yang berbeda. Sebagai contoh dalam adat salah satu suku asli, apabila sudah diadakan upacara adat Mangkok Merah dapat dimaknai bahwa seluruh suku tersebut di seluruh Kalimantanakan siap membantu. Hal itu terbukti dalam konflik sosial yang pernah terjadi di Kalimantan Timur maupun provinsi lain di Pulau Kalimantan.

Berdasarkan analisis wacana kritis (dimensi tekstual, dimensi praktik wacana, dan dimensi praktik sosial budaya), dalam percakapan warga dalam grup facebook 'Bubuhan Samarinda', dapat diidentifikasi potensi konflik sosial di Kota Samarinda. Potensi konflik sosial di Kota Samarinda yang didominasi faktor kesukuan didorong tingginya primordialisme warga Kota Samarinda. Selain itu, adanya upaya propaganda bahwa suku tertentu harus disegani. Suku asli tersebar di kabupaten/kota di Kalimantan Timur dan Samarinda sebagai ibukota provinsi menjadi tuan rumah bagi sukusuku tersebut. Dalam grup facebook 'Bubuhan Samarinda' terdapat unggahan-unggahan yang mempropagandakan bahwa suku tertentu harus disegani. Hal itu bisa dipahami sebagai bagian untuk eksistensi diri sebagai suku asli di Kota Samarinda.

Stigma di atas ada kaitannya dengan sejarah konflik antarsuku yang pernah terjadi di Kalimantan, seperti Sampit dan Sambas. Konflik di suatu daerah seolah menjadi model bagi daerah-daerah lain. Hal itu dapat dipahami karena konflik antarsuku yang pernah terjadi seperti mengulang kembali sejarah pertikaian antarsuku yang terjadi di beberapa daerah. Sejarah kelamseolah menjadi dendam yang tidak berkesudahan sehingga akan mudah untuk muncul lagi apabila terdapat pemantiknya (Narwoko, 2004: 181). Dalam lingkungan suku 
asli sendiri seolah terjadi persaingan antarsuku untuk disebut sebagai suku asli.

Sebagian warga dalam tuturan grup facebook 'Bubuhan Samarinda'mengungkapkan bentuk-bentuk ancaman dengan 'ilmu-ilmu' kesukuan tertentu untuk menunjukkan eksistensinya. Menurut Maunati (2006: 9) citra yang paling populer tentang Kalimantan selama ini adalah yang berkaitan dengan perburuan kepala. Para pemburu kepala dan orang-orang Dayak liar telah ditulis secara luas dan telah menjadi atraksi utama di Kalimantan Timur dan bahkan pulau Kalimantan secara keseluruhan. Miller (1946 dalam Maunati, 2006: 9) menulis dalam buku Black Borneo bahwa praktik memburu kepala bisa dijelaskan dalam kerangka supernatural yang oleh orang-orang Dayak diyakini ada di kepala manusia.

Pesan yang ingin disampaikan dibalik propaganda seperti itu bahwa keberadaan suku asliharus dihormati. Selain itu, suku-suku pendatang diharapkan dapat menghormati dan menghargai adat suku asli. Propaganda dapat juga dimaknai sebagai ultimatum bagi para pendatang yang tidak menghargai adat sukusuku asli dapat bernasib sama dengan pendatang di daerah-daerah yang pernah terjadi konflik di pulau Kalimantan. Prinsipnya apabila suku-suku pendatang dapat bersikap dan bertindak baik terhadap suku asli, suku asli pun akan bersikap dan bertindak jauh lebih baik. Kekerasan yang dilakukan oleh suku asli sebagai sebuah keterpaksaan dalam upaya untuk mempertahankan diri.

Propaganda tersebut didukung dengan adanya provokasi konflik antara suku asli dengan pendatang. Memang sulit menghilangkan stigma suku asli dan pendatang. Keberadaan suku pendatang yang seolah harus tunduk terhadap suku asli Kalimantan Timur. Resistensi konflik suku asli dan pendatang membesar dengan adanya stigma bahwa pendatang hanya mengeksploitasi kekayaan Kalimantan. Kalimantan Timur memang kaya dengan sumber daya alam. Hal itulah yang menjadi daya tarik bagi para pendatang. Maraknya pendatang ke Kota Samarinda membuat stereotipe pendatang hanya untuk mengeruk kekayaan alam di Kalimantan Timur.

Fakta bahwa para pendatang lebih banyak memegang kendali perekonomian tidak dapat dinafikkan. Kecemburuan sosial pun muncul. Hal itu rupanya menjadi salah satu pemicu dalam perdebatan bernuansa SARA dalam grup facebook 'Bubuhan Samarinda'. Kecemburuan sosial tersebut berimbas timbulnya stereotip bahwa pendatang menjadi sumber masalah di Kota Samarinda. Berbagai persoalan yang muncul di Kota Samarinda seperti banjir, kriminal dan lainnya sering disangkutpautkan dengan banyaknya pendatang. Jadi, apabila apa yang muncul di Kota Samarinda dan ada yang mengunggah dalam grup facebook 'Bubuhan Samarinda', hampir selalu ada yang mengaitkannya dengan keberadan pendatang.

Provokasi antara suku asli dan pendatang serta stereotipe pendatang hanya mengeruk kekayaan bumi Kalimantan Timur timbul karena adanya kecemburuan sosialekonomi. Kecemburuan sosial antara suku asli dan pendatang serta pendatang sebagai sumber masalah merupakan bentuk akumulasi dari kesenjangan sosial-ekonomi. Suku asli yang realita sosial-ekonomi tertinggal dibandingkan pendatang adalah suku Dayak. Tempo (1999 dalam Maunati, 2006: 4) pernah membuat laporan yang mengungkapkan bahwa banyak tokoh terkemuka dalam organisasi Dayak di Kalimantan Timur meramalkan bahwa situasi Kalimantan seperti 'api dalam sekam' yang bisa meledak kapan saja. Sejumlah pakar melaporkan bahwa banyak keberetan dan keluhan-keluhan ekonomi yang sama yang ikut menyumbang bagi munculnya konflik di Kalimantan Barat juga ditemukan di Kalimantan Timur.

Maunati (2006: 4) berpendapat seperti di Kalimantan Barat, Dayak Kalimantan Timur juga merasa terluka dan marah karena tiadanya kekuatan politik mereka dan tampaknya secara ekonomi mereka sudah kalah total dari kelompok-kelompok migran (pendatang) yang lebih kemudian datang. Amuk massa yang terjadi karena kesenjangan sosial-ekonomi akan dapat mengendur apabila sumber-sumber produksi yang ada terbagikan secara adil (Narwoko, 2004: 181). Oleh karena itu, kesenjangan ekonomi antara penduduk asli dengan pendatang harus diperkecil untuk meminimalkan potensi konflik sosial.

Berbagai potensi kekerasan yang ada diperparah keberadaan ormas kesukuan. Ormasormas kesukuan marak di Kalimantan Timur khususnya di Kota Samarinda. Ormas-ormas tersebut mengatasnamakan suku-suku tertentu. Dampak positif keberadaan ormas-ormas tersebut tentunya adanya forum untuk menyampaikan 
aspirasi kesukuan, terutama bidang politik. Hanya saja ada oknum-oknum ormas yang justru menimbulkan keresahan di masyarakat dengan melakukan aksi premanisme berkedok ormas kesukuan.

Dalam kehidupan sosial di Kota Samarinda, apabila terjadi gesekan antarwarga berlatarbelakang kesukuan yang berbeda terlebih lagi keduanya anggota ormas yang berbeda, peluang terjadinya konflik akan semakin besar. Sebagai buktinya konflik sosial yang terjadi di Nunukan pada tanggal 12 Juli 2007. Konflik tersebut bermula karena pribadi yang berlainan suku dan kebetulan anggota ormas yang berbeda. Konflik serupa dalam skala kecil sering terjadi di Kota Samarinda. Bentrok antarormas kesukuan yang dipicu perebutan jasa pengamanan juga beberapa kali terjadi di Kota Samarinda. Keberadaan ormas-ormas kesukuan kerap dimanfaatkan oleh pihak-pihak tertentu sebagai dukungan (backing), seperti dalam kasus sengketa lahan. Sengketa lahan yang awalnya kasus perseorangan dapat melebar menjadi konflik antarormas dan antarsuku. Disadari atau tidak, keberadaan ormas-ormas tersebut justru memperuncing perbedaan yang ada. Sekat antarsuku semakin jelas dan warga seperti dikotak-kotakkan. Akibatnya, ormas-ormas kesukuan di Kalimantan Timur utamanya di Kota Samarinda cenderung mendapat stereotip negatif.

Berbagai hasil identifikasi potensi konflik sosial dalam percakapan warga grup facebook 'Bubuhan Samarinda' merupakan representasi kehidupan sosial di Kota Samarinda. Dalam skala yang lebih luas kondisi sosial masyarakat di Kota Samarinda dapat menjadi gambaran umum masyarakat di Kalimantan Timur. Konflik linguistik dalam grup facebook Bubuhan Samarinda merupakan bentuk letupanletupan tersembunyi dalam benak warga Kota Samarinda. Bahkan dapat diasumsikan konflik linguistik dalam media sosial seperti grup facebook 'Bubuhan Samarinda' merupakan puncak gung es potensi konflik sosial di Kota Samarinda.

Gejala-gejala yang tampak di Kota Samarinda berdasarkan hasil identifikasi tersebut merupakan gejala yang hampir sama yang juga terjadi di daerah-daerah konflik sebelumnya (Kalteng dan Kalbar). Begitu juga pada dasarnya terdapat persamaan antara konflik etnik di Kalteng pada 2001 dengan yang terjadi di
Kalbar pada 1999 dan sebelumnya (Ruslikan, 2001: 6). Sebelum konflik Dayak dan Madura di Sampit dan Sambas sebelumnya juga berkembang stereotip yang berupa label negatif tentang suku tertentu yang tidak menunjukkan ciri-ciri kemanusian.

Menurut Soemardjan (Ruslikan, 2001: 4) dimana ada dua atau beberapa suku hidup sebagai tetangga dekat maka karena kebudayaannya yang berbeda, selama hubungan antara mereka itu, tidak dapat dihindarkan tumbuhnya bibit-bibit konflik sosial atau konflik budaya. Dalam kurun waktu tertentu konflik antaretnis (suku) belum meledak, maka itu semua hanyalah jeda sosial (konflik yang berhenti sementara) yang fungsinya sekadar menunda konflik terbuka yang sesungguhnya (Narwoko, 2004: 182).

\section{Kesimpulan}

Berdasarkan analisis wacana kritis percakapan warga dalam grup facebook 'Bubuhan Samarinda' dapat diidentifikasi potensi konflik sosial di Kota Samarinda. Pertama, adanya potensi konflik bernuansa SARA yang didominasi faktor kesukuan. Kedua, tingginya primordialisme warga kota Samarinda, Ketiga, adanya upaya propaganda eksistensi suku asli. Keempat, adanya provokasi konflik antara suku asli dengan pendatang. Kelima, persepsi bahwa pendatang hanya mengeksploitasi kekayaan Kalimantan. Keenam, kecemburuan sosial antara penduduk asli dengan pendatang. Kecemburuan sosial tersebut berimbas timbulnya persepsi bahwa pendatang menjadi sumber masalah di Kota Samarinda. Ketujuh, potensi kekerasan menguat karena keberadaan organisasi massa yang terorganisir berlatar kesukuan yang dimanfaatkan oknum tertentu.

Konflik linguistik percakapan warga dalam grup facebook 'Bubuhan Samarinda' belum menjadi pemicu konflik nyata di masyarakat Kota Samarinda, seperti yang terjadi di Tanjung Balai, Sumatera Utara. Hanya saja konflik linguistik yang terus berkembang merupakan 'api dalam sekam' yang sewaktuwaktu dapat menjadi konflik sosial yang nyata. Satu hal yang perlu disadari, konflik linguistik ini merupakan representasi kondisi sosial warga Kota Samarinda. Dengan demikian, perlu dipahami bahwa ada potensi konflik dalam kehidupan nyata di masyarakat Kota Samarinda yang sewaktu-waktu bisa pecah. Berbagai potensi 
konflik sosial tersebut sangat rentan dimanfaatkan pihak-pihak yang tidak bertanggungjawab untuk kepentingan tersembunyi, seperti untuk kepentingan politik. Potensi konflik tersebut akan semakin besar apabila dihubunghubungkan dengan isu keagamaan. Oleh karena itu, sinergi berbagai pendekatan keilmuan perlu dilakukan untuk menemukan solusi yang konprehensif. Selain itu, intervensi dan tindakan nyata harus dilakukan pemerintah Kota Samarinda dan Provinsi Kalimantan Timur untuk meredam potensi konflik sosial di Kota Samarinda. Penelitian tindak lanjut dengan pendekatan linguistik untuk mempercepat asimilasi antarsuku di Kota Samarinda perlu segera dilakukan.

\section{Daftar Pustaka}

Ahmadi F., Y.D. (2014). "Analisis Wacana Kritis: Ideologi Hizbut Tahrir Indonesia dalam Wacana Kenaikan Harga BBM 2013 di Buletin Al-Islam yang berjudul 'Menaikkan Harga BBM: Menaikkan Kemiskinan"'. Metalingua: Jurnal Penelitian Bahasa, 12 (2), 253-265.

BanjarmasinPost. (2011). Usai Sidang, Sembelih Hewan. Diakses dari http://komisi kepolisianindonesia.com/umum/read/33 08/usai-sidang-sembelih-hewan.html pada 3 November 2016.

BPS. (2016). Jumlah Penduduk Tahun 2013. Diakses dari https://samarindakota.bps. go.id/linkTableDinamis/view/id/2 pada 25 September 2016.

Djajasudarma, T.F. (1993). Metode Linguistik: Ancangan Metode Penelitian dan Kajian. (W. Nadeak, Ed.) (I). Bandung: PT Eresco.

Eka, W. (2007). Kalimantan Diambang Perang Etnis? Berpolitik.com. Diakses dari http://www.berpolitik.com/news.pl?nid= $6399 \&$ cid $=21 \&$ gid $=25$ pada 11 September 2016.

Hepburn, A., \& Potter, J. (2007). "Discourse Analytic Practice" dalam C. Seale, G. Gobo, J. F. Gubrium, \& D. Silverman (Eds.), Qualitative Research Practice (II, p. 168). Great Britain: Cromwell Press Ltd.

Keraf, G. (2006). Diksi dan Gaya Bahasa (16th ed.). Jakarta: Gramedia Pustaka Utama.
Krisdiantoro.(2010). Inilah Kronologi Bentrok Warga di Tarakan. Tribunnes.com. Diakses dari http://www.tribunnews. com/regional/2010/09/29/inilahkronolgi-bentrok-warga-di-tarakan pada 11 September 2016.

Maunati, Y. (2006). Identitas Dayak: Komodifikasi dan Politik Kebudayaan. (N. Ismah, Ed.) (II). Yogyakarta: PT LKiS Pelangi Aksara.

Miles, M.B., \& Huberman, A.M. (1992). Analisis Data Kualitatif. (T.R. (Penerjemah) Rohidi, Ed.) (I). Jakarta: Penerbit Universitas Indonesia.

Moleng, L.J. (1994). Metodologi Penelitian Kualitatif (25th ed.). Bandung: PT Remaja Rosdakarya.

Narwoko, J.D. (2004). Sosiologi Teks Pengantar dan Terapan. (J.D. Narwoko \& B. Suyanto, Eds.) (I). Jakarta: Kencana.

Primordialisme. (2016). Diakses dari https://id. wikipedia.org/wiki/Primordialisme pada 11 September 2016.

Prokal.co. (2016). Gara-gara Banjir, Gubernur Minta Samarinda Tak Lagi Terima Pendatang. Diakses dari http://news. prokal.co/read/news/912-banjirgubernur-minta-samarinda-tak-lagiterima-pendatang pada 11 September 2016.

(2016). Lebih 500 Ormas Tak Terdaftar. Diakses dari http://radar kaltim.prokal.co/read/news/687-lebih500-ormas-tak-terdaftar pada 11 September 2016.

Pruitt, D.G., \& Rubin, J.Z. (2011). Teori Konflik Sosial. (M. Khatamie, Ed.) (III). Yogyakarta: Pustaka Pelajar.

Purbani, W. (2009). Analisis Wacana Kritis dan Analisis Wacana Feminis. Diakses dari http://staff.uny.ac.id/system/files/pengab dian/dr-widyastuti-purbani-ma/analisiswacana-kritis.pdf pada 23 Februari 2016.

Ruslikan. (2001). Konflik Dayak-Madura di Kalimantan Tengah: Melacak Akar Masalah dan Tawaran Solusi. Journal Universitas Airlangga, XIV Nomor, 112. Diakses dari http://journal.unair. ac.id/konflik-dayak-madura-dikalimantan-tengah-article-2583-media- 
15-category-.html pada 5 November 2016.

Singh, I. (2006). Bahasa dan Etnisitas dalam L. Thomas \& S. Wareing (Eds.)Bahasa, Masyarakat, \& Kekuasaan (I, pp. 136164). Malang: Pustaka Pelajar.

Thornborrow, J. (2006). Bahasa dan Identitas dalam L. Thomas \& S. Wareing (Eds.) Bahasa, Masyarakat, \& Kekuasaan (I, pp. 223-251). Malang: Pustaka Pelajar.
Timur, T.P.D. S.P.K. (2013). Laporan Akhir Pemetaan Daerah Rawan Bencana Sosial di Kalimantan Timur. Samarinda: Dinas Sosial Provinsi Kalimantan Timur.

Undang-undang Nomor 7 Tahun 2012 Tentang Penanganan Konflik Sosial. 2012.

Vivaborneo.com. (2012). Kubar Rusuh, Pasar Barong Tongkok Dibakar.Diakses dari http://www.vivaborneo.com/kubarrusuh-pasar-barong-tongkokdibakar.htm pada 11 September 2016. 